\title{
Peran Perempuan Pedagang Sayur Keliling Dalam Menopang Ekonomi Keluarga Pada Masa Pandemi COVID-19 di Kelurahan Pagesangan Kecamatan Mataram Kota Mataram
}

\author{
Florentina Juita' ${ }^{1}$, Mas $^{`} a^{2}{ }^{2}$, Arif $^{3}$ \\ ${ }^{1}$ Pendidikan Geografi, Universitas Muhammadiyah Mataram, ftorentina45@gmail.com \\ ${ }^{2}$ Pendidikan Geografi, Universitas Muhammadiyah Mataram, sitimasad@gmail.com \\ ${ }^{3}$ Pendidikan Geografi, Universitas Muhammadiyah Mataram, arif83@gmail.com
}

\section{INFO ARTIKEL \\ Riwayat Artikel: \\ Diterima: 18 September 2020 \\ Disetujui: 30 September} 2020

\section{Kata Kunci:}

Perempuan

Pedagang Sayur Keliling

Ekonomi Keluarga

\begin{abstract}
ABSTRAK
Abstrak: Kehidupan manusia tidak terlepas dari aspek ekonomi dimana kebutuhan itu selalu bertambah dari waktu ke waktu sesuai dengan tuntutan hidup manusia termasuk Pada Masa Pandemi COVID-19 Menyikapi kondisi ekonomi yang semakin tinggi maka yang berperan untuk mencari nafkah rumah tangga bukan saja laki-laki tetapi juga perempuan. Peneliatian ini bertujuan: untuk mengetahui peran perempuan pedagang sayur keliling dalam menopang ekonomi keluarga Pada Masa PandemiCOVID-19di kelurahan Pagesangan Kecamatan Mataram Kota Mataram, apa saja kendala yang dihadapi perempuan pedagang sayur keliling dalam menopang ekonomi keluarga Pada Masa Pandemi COVID-19 di kelurahan Pagesangan Kecamatan Mataram Kota Mataram. Metode yang digunakan dalam penelitian ini adalah metode deskriptif dengan pendekatan kualitatif. Metode penentuan informan adalah purposive sampling. informan dalam penelitian ini adalah informan kunci dan informan biasa. Metode pengumpulan data yang digunakan adalah metode observasi, metode wawancara dan metode dokumentasi. Jenis data kualitatif. Sumber data yaitu data primer dan data sekunder. Instrumen dalam penelitian ini adalah peneliti itu sendiri. Metode analisa data yaitu, data reduction (data reduksi), data display (Penyajian Data), dan conclusion drawing/verification. Hasil penelitian menunjukkan bahwa; perempuan pedagang sayur keliling selain aktif dalam melakukan pekerjaannya menjual sayur keliling mereka juga tidak meninggalkan kewajibannya sebagai ibu rumah tangga, dengan itu perempuanpermpuan pedagang ini mampu membantu menopang ekonomi keluarganya pada masa pandemi Covid-19, walaupun penghasilan di antara perempuan pedagang sayur ini berbeda-beda. Adapun kendala yang dihadapi perempuan pedagang sayur keliling diantaranya: terbatasnya modal usaha, tingkat persaingan, transportasi, faktor pendidikan dan faktor alam.
\end{abstract}

\begin{abstract}
Human life is inseparable from the economic aspect where the need always increases from time to time in accordance with the demands of human life, including during the COVID-19 Pandemic. This research aims: to determine the role of women mobile vegetable traders in supporting the family economy during the Pandemic Covid-19 in Pagesangan, Mataram, Mataram City, what are the obstacles faced by women vegetable traders in supporting the family economy during the COVID-19 Pandemic in Pagesangan sub-district, District Mataram Mataram City. The method used in this research is descriptive method with a qualitative approach. The method of determining informants is purposive sampling. The informants in this study were key informants and regular informants. The data collection method used was the observation method, interview method and documentation method. Types of qualitative data. Data sources are primary data and secondary data. The instrument in this study is the researcher himself. Data analysis methods are data reduction, data display, and conclusion drawing / verification. The results showed that; Besides being active in doing their work to sell mobile vegetables, women who sell mobile vegetables do not abandon their obligations as housewives, with that these women traders are able to help support their family's economy during the Covid-19 pandemic, even though the income among these women vegetable traders is different. -different. The obstacles faced by women who are mobile vegetable traders include: limited business capital, level of competition, transportation, educational factors and natural factors.
\end{abstract}

A. LATAR BELAKANG
Kehidupan manusia tidak terlepas dari aspek ekonomi dimana kebutuhan itu selalu bertambah dari waktu ke waktu sesuai dengan tuntutan hidup manusia, 100 
termasuk pada masa pandemi COVID-19. COVID-19 adalah kepanjangan dari sebuah pandemi coronavirus disease 2019. Penyakit menular dan mematikan yang disebabkan oleh SARS CoV-2, salah satu jenis dari koronavirus. Virus ini pertama kali diumumkan kepada masyarakat dunia pada tanggal 1 Desember 2019 di China, tepatnya di daerah Wuhan Provinsi Hubei, China. Kemudian Presiden Republik Indonesia Joko Widodo, juga telah mengumumkan kasus pertama positif COVID19 di Indonesia pada Senin, 2 Maret 2020 yang ditularkan melalui transmisi dari manusia ke manusia. Akibat penyebaran COVID-19 menyebabkan dampak seperti pada bidang pekerjaan dimana banyak dilakukan PHK, perubahan perilaku masyarakat terutama dalam bidang kesehatan, hingga pada dampak ekonomi sehingga banyak pekerja harian pelaku ekonomi tingkat bawah (pelayan restoran, ojek, pedagang kaki lima, dll) tidak dapat bekerja sehingga tidak mempunyai penghasilan. Menyikapi kondisi serta tuntutan ekonomi yang semakin tinggi maka yang berperan untuk mencari nafkah dalam rumah tangga bukan saja laki-laki tetapi juga perempuan. Hakekatnya semua anggota rumahtangga turut bertanggung jawab atas kehidupan bersama.

Hasil pembahasan peneliti menemukan bahwa 1) Perempuan bekerja bukanlah hanya mementingkan diri sendiri, mereka bekerja karena tuntutan ekonomi dan tekanan kebutuhan hidup yang terus menerus semakin tinggi. Faktor motivasi istri bekerja lebih mengarah kepada kebutuhan ekonomi yang tidak mampu dipenuhi sepenuhnya. [1] Faktor ekonomi menjadi landasan pacu bagi perempuan untuk menjadi pedagang semata demi kesejahteraan keluarga, sumbangan penghasilan perempuan pedagang berperan dalam keberlangsungan rumah tangga.[2] Perempuan memiliki peran yang dominan dalam membantu meningkatkan kesejahteraan keluarga yaitu bisa melalui berdagang keliling.[3] Pedagang perempuan memiliki kemampuan untuk mengatur, mempengaruhi, menentukan, bahkan mendominasi suatu arus pertukaran barang, tenaga kerja bahkan modal.[4] perempuan berkontribusi dalam menafkahkan keluarga melalui kegiatan berdagang.[5]

Berbagai penelitian sebelumnya lebih condong mengkaji pada aspek peran perempuan dalam berdagang di pasar tradisional, perempuan berkontribusi memberikan nafkah ekonomi keluarga melalui berdagang. Sementara aspek peran perempuan pedagang keliling di era covid-19 belum banyak orang yang melakukan penelitian baik pada lokasi, objek dan metode penelitian yang digunakan, selain itu banyak perempuan-perempuan berjualan keliling kampung, perumahan dan kantor-kantor setiap hari. Karena rutinitas berdagang keliling seorang perempuan merupakan hal baru, karena secara kekeluargaan seorang laki-laki yang pantas untuk melakukan kegiatan berjualan keliling karena di dukung fisik yang kuat. Akan tetapi di kota Mataram ternyata banyak perempuan yang melakukan berjualan keliling kampung. Perempuan pedagang keliling merupakan profesi baru yang biasanya mereka berjualan di pasar tradisional maupun pasar modern.

Perempuan juga mempunyai tugas dan fungsi dalam mendukung rumahtangga meskipun masih ada yang beranggapan bahwa tugas perempuan dalam rumahtangga adalah hanya untuk melahirkan keturunan, mengasuh anak, melayani suami dan mengurus rumahtangga. Ketimpangan ini terjadi akibat adanya struktur budaya masyarakat yang merupakan konstruksi sosial yang telah ada sejak berabad-abad yang lalu sehingga telah menjadi hukum yang tidak tertulis.

Persoalan yang terjadi dalam masyarakat adalah peran perempuan di dalam menopang ekonomi keluarga kadang kala diremehkan dan dianggap hanya sebagai pendapatan sampingan. Pemikiran dimasyarakat bahwa laki-laki merupakan pencari nafkah di dalam suatu rumah tangga atau keluarga demikian melekat didalam kehidupan masyarakat, akibatnya perempuan bekerja dipandang hanya sebagai tambahan atau penghasilan sampingan. Padahal fakta dilapangan menunjukan bahwa betapa besarnya kontribusi perempuan bekerja terhadap ekonomi rumah tangga.[6]

Salah satu pekerjaan yang dilakukan oleh wanita atau ibu rumah tangga baik sebelum pandemi maupun pada masa pandemi Covid-19 adalah sebagai pedagang, pekerjaan ini dipilih merupakan pekerjaan informal dimana wanita atau ibu rumah tangga dapat membagi waktu antara pekerjaan dan keluarga. Masuknya wanita dalam pekerjaan berdagang yakni salah satunya sebagai pedagang sayur keliling. Pedagang sayur keliling memiliki peranan penting dalam membantu pendapatan ekonomi keluarga household economy.[7]

Pedagang sayur keliling mempunyai peran yang penting dalam mendukung pertumbuhan ekonomi keluarga. Pekerjaan menjajakan sayur keliling merupakan pekerjaan di sektor informal sehingga tidak membutuhkan kualifikasi pendidikan tertentu maupun seleksi yang rumit dan ketat bagi yang ingin bekerja. Orang-orang yang tidak memiliki kesempatan dan kemampuan yang memadai untuk tertampung di sektor formal kemudian menciptakan kegiatan ekonomi di sektor informal sebagai alternative terbaik mereka untuk bertahan hidup. Pekerjaan berdagang sayur keliling tidak memerlukan modal yang banyak serta ketrampilan atau kecakapan tertentu.

Pasar Pagesangan adalah salah satu Pasar tradisional di Kota Mataram yang ditunjuk sebagai pasar percontohan pasar ini berada di Kelurahan Pagesangan dimana para pedagang sayur keliling ini banyak yang berbelanja di pasar tersebut. Keberadaan pedagang sayur keliling ini pada hakekatnya merupakan mitra bagai pedagang sayur yang berada di pasar pagesangan 
tersebut. Melihat kondisi pedagang sayur keliling yang banyak didominasi kaum perempuan dan berjualan baik dengan cara mengendari sepeda Motor, maupun berjalan kaki dalam membawa dagangan sayurnya, tak bisa dipungkiri menimbulkan ketertarikan tersendiri untuk mengkaji lebih dalam seluk beluk kehidupan mereka dan bagaimana mereka melakukan aktivitas berdagang sayur keliling apalagi dengan eksistensi ritel modern ternyata pedagang tradisional dalam hal ini pedagang sayur keliling masih tetap eksis bahkan semakin menjamur.

Perempuan pedagang sayur keliling memiliki karakteristik dengan PKL lainnya, cara berdagangnya dengan menggunakan sepeda motor dengan mengelilingi perumahan padat, namun sisi penghasilannya hanya cukup untuk kehidupan keluarga saja.[8] Terdapat berbagai macam strategi dagang yang di terapkan oleh para pedagang sayur keliling di diantaranya; strategi dalam menetapkan harga, strategi dalam penjualan barang (produk), strategi dalam mencari pelanggang serta mempertahankan pelanggang dan strategi dalam pengambilan keuntungan.[9] Tujuan artikel menjelaskan peran perempuan pedagang sayur keliling dalam menopang ekonomi pada masa pandemi covid-19 keluarga di Kelurahan Pagesangan Kecamatan Mataram Kota Mataram.

\section{B. METODE PENELITIAN}

Penelitian ini menggunakan metode kualitatif. Kondisi objektif yang alamiah merupakan instrumen kunci, teknik pengumpulan data dilakukan secara triangulasi (gabungan), analisis data bersifat induktif dan hasil penelitian kualitatif lebih menekankan makna daripada generalisasi. Penelitian ini akan dilaksanakan di kelurahan Pagesangan Kecamatan Mataram Kota Mataram.

Informan dalam penelitian ini adalah Informan kunci adalah mereka yang mengetahui dan memiliki berbagai informasi pokok yang diperlukan dalam penelitian atau informan yang mengetahui secara mendalam permasalahan yang sedang diteliti. Informan kunci dalam penelitian ini yaitu Perempuan pedagang sayur keliling Pada Masa Pandemi Covid-19 di Kelurahan Pagesangan Kecamatan Mataram Kota Mataram. .Informan biasa adalah informan yang ditentukan dengan dasar pertimbangan mengetahui dan berhubungan dengan permasalahan. Adapun informan biasa dalam penelitian ini yaitu kepala Kelurahan Pagesangan .

Metode pengumpulan data menggunakan metode observasi, wawancara dan dokumentasi terkait peran perempuan pedagang sayur keliling. Teknik analisis data Menggunakan tiga tahapan yaitu data reduction, data display, dan conclusion drawing atau verification.

\section{HASIL DAN PEMBAHASAN}

\section{Peran Perempuan Pedagang Sayur Keliling Dalam Menopang Ekonomi Keluarga Pada Masa Pandemi Covid-19}

Wanita mempunyai dua posisi atau status dalam kegiatan bekerja, yaitu dalam pekerjaan rumah tangga dan pekerjaan yang menghasilkan pendapatan. Besarnya peranan wanita dalam pekerjaan rumah tangga dan pekerjaan dibidang mencari nafkah tidak selalu bersamaan dengan besarnya pengaruh wanita di dalam maupun di luar rumah tangganya, perlu memperhatikan faktor-faktor wewenang keluarga serta sumberdaya pribadi yang disumbangkan pria dan wanita dalam keluarganya.

Dalam menjalankan peranannya, kaum perempuan dihadapkan pada peranan ganda, baik di sektor domestik maupun di sektor publik. Peran perempuan dalam pekerjaan rumah tangga dan pekerjaan dibidang mencari nafkah tidak selalu bersamaan dengan besarnya pengaruh perempuan di dalam maupun di luar rumah tangganya, perlu memperhatikan faktor-faktor wewenang keluarga serta sumberdaya pribadi yang disumbangkan laki-laki dan perempuan dalam keluarganya. Peranan domestik perempuan adalah peranan sosial yang terkait dengan aktivitas internal rumah tangga, seperti memasak, mengurus anak, melayani suami. Berikut pernyataan dari Ibu Husnil Yakin usia 50 tahun,

"Dalam keluarga saya ngurusin keluarga, kegiatan saya di rumah mulai dari ngurus anak, bersih-bersih rumah, masak, mencuci kalau sudah selesai semua ya mengurus ternak dan tanaman.

Perempuan pedagang sayur keliling selain aktif dalam melakukan pekerjaannya menjual sayur mereka juga tidak meninggalkan kewajibannya sebagai ibu rumah tangga untuk mengelola rumah tangga dan mengasuh anak. Perempuan pedagang sayur keliling dapat menyeimbangkan antara menjual sayur dan di rumah tangga. Pembagian waktu yang tepat adalah kunci utama keseimbangan tersebut. Apabila para Perempuan pedagang sayur keliling ini selesai menjajakan dagangannya mereka akan mengerjakan tugas utama di rumah tangga.

Selain mengurus kegiatan rumah tangga perempuanperempuan pedagang sayur keliling juga mengajarkan tata krama, sopan santun dan kedisiplinan pada anakanak mereka. Berikut pernyataan dari Ibu Sumiaty usia 35 tahun,

"Saya mengajarkan pendidikan tata krama, sopan santun, dan kedisiplinan. Kalau pendidikan 
agama saya ajarindoa. Kalau misalnya ada anggota keluarga saya yang sakit, saya membawa ke puskesmas terdekat."

Tidak hanya berperan dalam pekerjaan rumah tangga, perempuan juga berperan dalam pendidikan dan kesehatan untuk anggota keluarganya. Pendidikan keluarga untuk anak-anak mereka diterapkan dengan cara mengajarkan, memberi arahan dan nasehat. Begitu juga untuk sosialisasi anak dalam keluarga dan juga masyarakat juga diajarkan dan diarahkan. Mereka juga memberikan pendidikan agama bagi anggota keluarganya,dengan cara mengajarkan Doa kepada anak-anaknya. Selain pendidikan, mereka juga memperhatikan kesehatan anggota keluarganya. Apabila ada anggota keluarga yang sakit, pertolongan pertama yang dilakukan dengan membawanya ke puskesmas terdekat.

Berikut pernyataan dari Ibu Isyah usia 45 tahun menyatakan:

"Saya berdagang sayur keliling sudah 20 tahun tujuannya adalah untuk membantu ekonomi keluarga, modal pertama dua ratus ribu rupiah kemudian keuntunganya kira-kira Rp. 100.ooo, saya berjualan mulai dari jam delapan pagi sampai dengan jam dua belas. Peneliti lanjutkan Ibu kenapa tidak menggunkan sepeda motor, walah Mbk mana ada duitnya untuk beli motor, kalau rumah apakah milik sendiri, ya milik sendiri, ibu tinggal dimana, saya tingal di Babidas, kalau boleh tahu Suami Ibu pekerjaannya, suami saya tukang bangunan, apakah ibu punya anak, ada mbk dua orang dan sudah bekerja, pendidikan Ibu kalau boleh saya tahu.

Ibu Husni Yakin usia 50 tahun menyatakan:

"yang jelas saya dapat merasakan bisa membantu pendapatan keluarga, karena saya sekarang ini menjadi tulung punggung keluarga berhubung suami saya sudah meninggal. Berjualan sayur ini sudah saya lakukan sejak bujangan dengan modal waktu itu cuman $R p$. 50.ooo,- hingga mempunyai anak empat orang, tiga orang sudah menikah dan satu orang masih sekolah jadi biaya saya cuman untuk berdua saja, keuntungan saya berkisar antara 50 ribu rupiah sampai 100 ribu rupiah, saya berjualan mulai jam setengah delapan pagi sampai jam dua belas. Kendala yang sering saya hadapi adalah banyaknya pelanggan yang ngutang, saingan yang banyak terutama mereka yang punya motor, karena naik motor lebih cepat sedangkan saya tidak bisa naik motor.Karena tidak ada pekerjaan lain yang bisa saya lakukan karena saya tidak tamat sekolah. (wawancara dilakukan tanggal 24 mei 2020)

Ibu Siti Maryam 49 tahun memberikan pernyataanya:
"Tujuan saya adalah untuk membantu suami guna menambah penghasilan maklum suami saya bekerjanya sebagai tukang bangunan yang penghasilan belum tentu, walupun waktu itu modal saya hanya seratus lima puluh ribu rupiah, sedangkan keuntungannya seharinya kurang lebih Rp. 80.ooo,- saya julan sayur ini sudah 27 tahun, dan saya mulai julan dari jam setengah sembilan pagi sampai kira-kira setengah dua belas, saya tinggal di lingkungan pagesangan Timur. pendidikan saya SD, tapi walaupun saya sekolahnya SD tapi anak saya yang dua orang semuanya lulus SMA seringkali saya yang pejalan kaki di dahului oleh pedagang yang menggunakan sepeda motor, banyak penjual sayur kelilig dan banyak yang ngutang".

Kemudian peneliti lanjutkan dengan informan yang berjualan di lingkungan Babidas, Karomah usia 45 tahun menyatakan:

"karena pendapatan Bapak sebagai kuli bangunan tidak mencukupi sehingga saya mencoba membantu dengan cara berjualan seperti ini, seperti menjual sayur bayam, pucuk singkong, terong, tempe, tahu, pisang. Ikan, ayam dan banyak lagi mbk yang dijual yah untuk kepentingan rumah tangga, lumayan bisa membantu memenuhi kebutuhan. sementara modal yang saya gunakan pertama kali berjualan adalah Rp. 50.ooo,- sedangkan keuntungannya tidak banyak kira-kira $R p$. 75.ooo, sampai $R p$. 10o.ooo,- pada saat mulai berjualan usia saya kurang lebih 20 tahun jadi masih anak-anak oleh karena itu saya tidak bisa sekolah, tetapi anakanak saya yang tiga orang semuanya sekolah SMA. Sekarang usia saya sudah 45 tahun dan saya berjualan di daerah lingkungan Babidas masuk Gang gitu mulai jam enam pagi sampai jam sebelas, hambatan didalam berjualan ini, walaupun saya sudah berjualan selama 24 tahun masih saja ada hambatan yaitu banyak saingan terutama mereka yang sudah pakai motor. (wawancara dilakukan tanggal 12 juli 2020 di pasar pagesangan)

Sumi usia 33 tahun memberikan keterangan :

"karena ingin bekerja untuk bantu suami sebagai pekerja toko, kalau pendapat suami sudah cukup buat sekolahin anak-anak dan penuhi kebutuhan keluarga, tapikan cari uang juga buat tabungan, sementara modal awal suami yang kasidan modal awal 200 ribu keuntungannya minimal 50.0oo, kalau suami selalu mendukung saya, kalau saat ini sih kita masih berjualan walaupun kita harus pakai masker. Wawancara tanggal o9 Agustus 2020).

Asni 50 tahun menyatakan: 
"Ingin mencari uang, karena saya tinggal dengan cucu yang masih kecil, kalau suami sudah meninggal, terus anak pergi kerja di luar negeri, sudah 27 tahun jualan, yang menjadi perbedaan dalam menjual sekarang sih kita harus berjualan sambil pakai masker karena sekarang kan masa Covid-19, kadang nggk jualan juga, kalau sekarang sih lebih banyak dirumah jadi jarang berjualan, Jadinya covid ini sangat berpengaruh karena covidini kita jarang berjualan.

Ternyata para pedagang sayur keliling memiliki tujuan dari berjualan sayur itu adalah untuk membantu kebutuhan ekonomi keluarga, karena hasil pendapatan Suami yang rata-rata tukang bangunan tidak cukup untuk keperluan hidup sehari-hari, sehingga para perempuan ini rela berjalan kaki dan ada juga yang mengendarai speda motor dari jam setengah enam hingga sampai jam dua belas siang untuk menjual sayur keliling. Melihat kontribusi yang diberikan oleh para perempuan pedagang sayur ini terhadap pendapat keluarga yang melakukan pekerjaan untuk menambah ekonomi keluarga. Kontribusi pedagang sayur keliling terhadap pendapatan rumah tangga adalah besarnya sumbangan atau bagian pendapatan dari pedagang terhadap keseluruhan pendapatan rumah tangga.Dari hasil penelitan juga, peneliti dapat menarik kesimpulan bahwa, terdapat pengaruh yang signfikan terhadap aktivitas ekonomi dan laju perekonomian perempuan pedagang sayur keliling karena pandemik.Dimana sebagian besar kegiatan ekonomi baik dibidang dibidang perdagangan mengalami penurunan pendapatan yang dikibatkan oleh pandemi itu sendiri.

Dengan demikian mereka melakukan peran bukan hanya untuk bekerja yang berkaitan dengan kedudukan dan kewajiban sebagai ibu rumah tangga saja, seperti: melayani suami, memasak, membersihkan rumah, mengasuh, mendidik dan mengatur perekonomian rumah tangganya. Tetapi juga membantu bagaimana caranya memenuhi kebutuhan keluargnya. Hal tersebut sejalan dengan penjelasan bahwa perempuan berperan ganda untuk menngunakan waktu sefektifnya, selainnya bernilai social karena dapat berinteraksi dnegan perempuan lainnya. Dalam bidang ekonomi peran perempuan cukup baik karena mampu mencukupi kebutuhan keluarga di rumah. Selain itu adanya tuntutan social agar tidak terjadi diskriminatif terhadap perempuan.[10] Perempuan mempunyai peran dalam sistem nafkah rumah tangga. Kontribusi perempuan dalam nafkah rumah tangga diperoleh melalui kegiatan produktif yang mereka lakukan. Kegiatan tersebut, di antaranya, adalah keterlibatan perempuan dalam pemasaran hasil tangkapan dan keterlibatan dalam kegiatan pengolahan hasil tangkapan.[5] Perempuan sangat tangguh, dan berepan ganda dalam mencari nafkah.[11]
Perempuan mempunyai dua peranan yaitu sebagai istri atau ibu rumah tangga yang melakukan pekerjaan rumah, pedagang adalah mereka tetap melakukan perannya sebagai ibu rumah tangga meskipun melakukan penjualan.[12] perempuan berperan ganda, dapat berperan sebagai pelukis batik, rumah tangga dan anggota PKK.[13]

Sebagai pengurus rumah tangga yang bertanggung jawab, wanita mengatur segala sesuatu didalam rumah tangga dan memperhatikan kesehatan keluarga untuk meningkatkan mutu hidup. Sehinggatercipta suasana tenang, tentram, dan damai bagi seluruh anggota keluarga.

Hasil penelitian menunjukan bahwa perempuan pedagang sayur keliling dapat menjalankan perannya sebagai ibu rumah tangga dengan baik. Hal ini dapat terlihat melalui peran perempuan yang bekerja sebagai pedagang sayur keliling, maka perempuan yang bekerja di bidang ini mendapatkan penghasilan keluarganya yang meningkat. Berdasarkan hasil penelitian bahwa perempuan pedagang sayur keliling dikelurahan pagesangan kecamatan mataram kota mataram sebagian besar mereka memiliki peran ganda baik sebagai seorang istri dan ibu maupun berperan sebagai pencari nafkah untuk membantu meningkatkan perekonomian keluarga tanpa meninggalkan tugas pokoknya. Dan yang menyebabkan kebanyakan perempuan ikut berpartisipasi dalam keluarga yang paling utama yaitu faktor ekonomi, melihat dari setiap kondisi keluarga yang peneliti wawancara kebanyakan dari mereka bekerja akibat faktor ekonomi mereka tidak tercukupi. Keluarga sejahtera adalah keluarga yang dibentuk berdasarkan atas perkawinan yang sah, mampu memenuhi kebutuhan hidup spiritual dan material yang layak, bertaqwa kepada Tuhan Yang Maha Esa, memiliki hubungan yang serasi, selaras dan seimbang antar anggota keluarga dengan masyarakat dan lingkungan.

\section{Kendala Yang Dihadapi Oleh Perempuan Pedagang Sayur Keliling Dalam Menopang Ekonomi Keluarga Pada Masa Pandemi Covid-19}

Kendala dapat diartikan sebagai halangan dan rintangan dalam menjalankan suatu usaha. Menjalankan suatu usaha tentu tidak seluruhnya berjalan sesuai dengan harapan, bisa terjadi adanya masalah-masalah seperti adanya kerugian serta adanya kendala yang dihadapi dalam menjalankan usaha yang didirikannya. Perempuan yang bekerja sebagai pedagang sayur keliling dalam menopang ekonomi keluarga pada masa pandemi Covid-19 tentunya tidak selalu mendapatkan keuntungan yang memuaskan diakibatkan karena adanya kendala dalam melakukan usaha tersebut. 
Sebagaimana yang dikemukakan oleh Ibu Isyah berusia 45 tahun menyatakan:

"yang menjadi kendala utama adalah modal usaha dan dilihat dari macam-macam sayur yang dijual, Ibu Isyah tidak memiliki banyak modal untuk untuk menambah jenis sayuran sehingga ketersediaan barang juga kurang dan hanya seadanya saja".

Ibu Nurhadiyah 40 tahun, menyatakan:

"Adapun yang menjadi kendala dalam melakukan penjualan keliling adalah terkait dengan keterbatasan modal yang menyebabkan saya harus menjual sayur sedikit"

Hal yang menjadi kendala bagi informan adalah kurangnya modal usaha, ketersediaan barang yang kurang. Yang menjadi kendala dalam meningkatkan ekonomi keluarga dalam penelitian ini adalah modal usaha. Keadaan ekonomi keluarga merupakan faktor yang sangat penting dalam kehidupan keluarga, ekonomi dalam keluarga meliputi keuangan yang dapat meningkatkan taraf hidup anggota keluarga. Dalam hal ini pada perempuan pedagang sayur keliling tentunya sangat membutuhkan modal untuk kemajuan usahanya.

Ibu Karomah umur 45 tahun berpendapat bahwa:

"Banyaknya orang yang berdagang dengan jenis usaha yang sama, belum lagi harus berjualan di tempat yang sama dengan penjual yang lain dan juga bersaing dengan pedagang-pedagang yang menggunakan motor"

Ibu Ramida usia 41 tahun menyatakan:

"kalau soal kendala sih banyak mbk macammacam mulai dari menjual sayur yang sama sampai dengan banyak saingan apalagi sekarang yang tepat pada masa pandemi Covid19 ini"

Kendala dalam menjalankan usaha berdagang sayur yaitu tingginya tingkat persaingan usaha pedagang keliling. Tingginya tingkat persaingan mengakibatkan kurangnya pendapatan perempuan pedagang sayur keliling

Ibu Karomah (45) dan Ibu Ana (31) tahun.

"Hambatan didalam berjualan ini, walaupun Ibu Karomah sudah berjualan selama 24 tahun masih saja ada hambatan yaitu tidak memiliki kendaraan sehingga ibu ini berjualan keliling dengan berjalan kaki" wawancara tanggal 12 juli 2020.

"Adapun yang menjadi kendala saya dalam melakukan penjualan selama berjualan baik sebelum masa pandemi Covid-19 maupun pada masa pandemi ini adalah saya tidak memiliki kendaraan yang bisa saya gunakan untuk melakukan penjualan keliling dan yang menyebabkan saya sering kali kelelahan"

Kendala utama perempuan pedagang sayur keliling dalam berdagang adalah keterbatasan kendaraan sehingga informan hanya bisa berjualan keliling dengan mengandalkan berjalan kaki sehingga barang yang dijajakan terbatas.

Perempuan pedagang sayur keliling pada masa pandemi Covid1-19 memiliki berbagai latar belakang pendidikan, yaitu:

Husnil Yakin pendidikan tidak tamat SD, Sumiayati Pendidukan SMA, Siti, Maryam Pendidikan SD, Isyah Pendidikan SD, Karomah Pendidikan SMP, Sumi Pendidikan SMP, Asni Pendidikan SD, Nurhadiyah Pendidikan SMP, Ramidah Pendidikan SMP dan Ana Pendidikan SMP.

Perempuan pedagang sayur keliling yang merupakan informan peneliti yang tingkat pendidikan hanya tamat Sekolah Dasar dan Sekolah Menengah Pertama tentunya sangat berpengaruh dalam pengembangan usahanya. Pendidikan sangatlah penting untuk melangkah menuju hari esok, seperti halnya dalam pencarian kerja bagi masyarakat. Pendidikan yang tinggi akan mempengaruhi mata pencaharian, semakin tinggi pendidikan yang diperoleh akan semakin tinggi pula tingkatannya.

Siti Maryam usia 49 tahun memberikan informasi bahwa :

"yang menjadi kendala dalam jualan ini itu, hujan, becek, jadi kesulitan untuk jualan, kalau sudah hujan ibu Maryam langsung pulang karena takut petir dan juga karena sekarang bertepatan dengan masa COVID 19 jadi terpaksa beliau lebih sering nggk jualan dan kendalanya sekarang itu karena COVID 19 jadi kita itu jarang jualan, kalau panas udah biasa kita itu”

Ibu Ramidah (49) tahun menyatakan:

"adapun yang menjadi kendala dalam melakukan penjualan sayur keliling sekarng adalah kita dibatasi oleh pemerintah untuk keluar rumah dan mewajibkan kita semua tetap di dalam rumah sehingga saya selaku penjual sayur kelilingpun terpaksa tidak bisa berjualan keliling solusinya selama ini seringkali saya berjualan dirumah saja dengan membangun tenda didepan rumah untuk menjual sayur sehingga saya tidak perlu berjalan keliling untuk berjualan.

Beberapa alasan tersebut sangat mempengaruhi pekerjaan perempuan pedagang sayur keliling, modal adalah salah satu kendala penghalang terbesar bagi mereka untuk meningkatkan usaha. Sedangkan faktor alam adalah ketentuan Allah dan itu juga jarang terjadi. Bagi pedagang sayur keliling kondisi alam sangat mempengaruhi pekerjaan mereka, karena dengan turunnya hujan maka dapat menghambat aktivitas mereka dalam menjual mereka tidak bisa bekerja dalam kondisi hujan sehingga pekerjaannya ditunda dan adapun yang menjadi solusi daripada penjual sayur iyu sendiria dalah menjual dagangan di depan rumah. 
Dalam mencari nafkah sebagai menjual sayur, tentu para perempuan pedagang sayur ini mengalami kendala sehingga mereka hanya bisa menghasilkan penghasilan yang terbatas dan kadang kurang mencukupi untuk kebutuhan sehari-hari. Kendala adalah salah satu faktor yang berepngaruh dalam memenuhi kebutuhan utama keluarga, adapun kendala yang dialami para perempuan pedagang sayur keliling tersebut adalah:

Pertama, Terbatasnya modal usaha, modal usaha merupakan dana yang diperlukan untuk membuat sebuah usaha untuk mencapai suatu tujuan. Tapi kita ketahui bahwa salah satu yang menjadi penghambat dalam menjalankan usaha adalah modal yang kurang. Pada umumnya perempuan yang membuka usaha memiliki penghasilan yang masih rendah sehingga kesulitan dalam mengembangkan usahanya karena hanya memiliki modal yang kurang sehingga mereka menjalankan usaha dengan seadanya saja.

Kedua, tingkat persaingan, persaingan merupakan bersaingnya para pedagang yang sama-sama berusaha mendapatkan keuntungan yang biasanya berusaha mengungguli persaingan dengan membesdakan harga produk yang dijualnya. Persaingan usaha perdagangan tentunya sangat mempengaruhi baik dari tingkat keuntungan karena banyaknya pedagang yang mendirikan usaha dengan jenis yang sama.

Ketiga, terbatasnya transportasi, transportasi diartikan sebagai pemindahan barang dan manusia dari tempat asal ke tempat tujuan. Keempat, faktor pendidikan, setiap manusia membutuhkan pendidikan, baik secara formal dan non formal. Adanya pendidikan maka manusia akan mempunyai wawasan yang luas dan pola pikir yang maju sehingga mendapat kesempatan bagi manusia untuk memilih jenis pekerjaan guna meemenuhi kebutuhan hidupnya. Perempuan pedagang sayur keliling yang merupakan informan peneliti yang tingkat pendidikan hanya tamat Sekolah Dasar dan Sekolah Menengah Pertama tentunya sangat berpengaruh dalam pengembangan usahanya. Pendidikan sangatlah penting untuk melangkah menuju hari esok, seperti halnya dalam pencarian kerja bagi masyarakat. Pendidikan yang tinggi akan mempengaruhi mata pencaharian, semakin tinggi pendidikan yang diperoleh akan semakin tinggi pula tingkatannya.

Kelima, Faktor alam, faktor alam merupakan sudah ketentuan Allah dan itu juga jarang terjadi. Bagi pedagang sayur keliling kondisi alam sangat mempengaruhi pekerjaan mereka, karena dengan turunnya hujan maka dapat menghambat aktivitas mereka dalam berjualan, mereka tidak bisa bekerja dalam kondisi hujan sehingga pekerjaannya ditunda.

Beberapa kendala tersebut, sejalan dengan temuan lainnya yang menemukan bahwa pedagang tradisional dan pedagang modern memiliki jumlah omzet yang berbeda, pedagang modern memiliki jumlah omzet lebih dibandingkan dengan pedagang tradisional.[14];[15]
Sementara, hubungan antara jam kerja dengan pendapatan pedagang sayur keliling memiliki nilai positif maksudnya semakin banyak jam kerja semakin banyak pendapatannya, sebaliknya akan bernilai negative.[16]

\section{SIMPULAN DAN SARAN}

Berdasarkan hasil penelitian yang telah dilakukan penulis mengenai peran perempuan pedagang sayur keliling dalam menopang ekonomi keluarga pada masa pandemi COVID-19 di kelurahan pagesangan kecamatan mataram kota mataram, maka penulis dapat mengambil kesimpulan sebagai berikut:

Perempuan pedagang sayur keliling dapat berperan dalam menopang ekonomi keluarga, baik perempuan yang masih memiliki suami maupun perempuan yang tidak lagi memiliki suami (janda). Faktor-faktor yang menyebabkan perempuan-perempuan tersebut berperan sebagai pedagang sayur keliling adalah rendahnya penghasilan suami, tingginya tingkat kebutuhan hidup, besarnya tanggungan anak dan biaya pendidikannya, adanya dorongan dari dalam diri untuk memperoleh kehidupan yang lebih mapan, dan adanya keinginan perempuan untuk mengekspresikan diri melalui bekerja.

Kendala dapat diartikan sebagai halangan dan rintangan dalam menjalankan suatu usaha. Menjalankan suatu usaha tentu tidak seluruhnya berjalan sesuai dengan harapan, bisa terjadi adanya masalah-masalah seperti adanya kerugian serta adanya kendala yang dihadapi dalam menjalankan usaha yang didirikannya. Perempuan yang bekerja sebagai pedagang sayur keliling dalam menopang ekonomi keluarga pada masa pandemi Covid-19 tentunya tidak selalu mendapatkan keuntungan yang memuaskan diakibatkan karena adanya kendala dalam melakukan usaha tersebut. Kendala yang dihadapi oleh perempuan pedagang sayur keliling dalam menopang ekonomi keluarga pada masa pandemi Covid-19 di Kelurahan Pagesangan Kecamatan Mataram Kota Mataram adalah karena terbatasnya modal usaha, tingkat persaingan, transportasi, dan faktor pendidikan. Pendapatan keluarga yang tidak menentu yang membuat mereka harus berusaha agar kebutuhan sehari-hari dapat terpenuhi. Pendapatan dari pekerjan suami mereka yang tidak tetap sehingga seorang ibu yang seharusnya hanya mendidik anak dirumah justru ikut turun dalam kegiatan di luar rumah untuk mencukupi kebutuhan keluarga.

Dengan demikian mengharapkan kepada perempuan pedagang sayur agar tetap melakukan tugastugas dan tanggung jawab dalam rumah tangga dengan baik, dalam upaya memenuhi kebutuhan ekonomi keluarga. Kepada masyarakat terutama pada kaum lakilaki (Suami) sebagai pemimpin yang bertanggung jawab dalam keluarga agar lebih bertanggung jawab dalam 
menafkahi keluarga dengan baik, dengan meningkatkan mata pencaharian agar mendapatkan penghasilan yang baik dan mencukupi kebutuhan keluarga. Kepada pemerintah terkait yang ikut serta dalam mensejahterakan ekonomi masyarakat agar dapat melakukan tugasnya dengan baik, dalam upaya memberikan bantuan usaha tepat pada tujuan utama, yaitu memberikan bantuan usaha atau modal pada masyarakat yang tepat. Dan lebih fokus dalam pendataan ekonomi masyrakat agar semua masyarakat terdata dengan baik.

\section{UCAPAN TERIMA KASIH}

Penulis mengucapkan terima kasih kepada semua pihak yang telah mendukung kegiatan penelitian ini dengan beraneka ragam data, dana penelitian sehingga penelitian ini selesai dengan baik.

\section{DAFTAR RUJUKAN}

[1] F. Fitriyani, "Peran Perempuan dalam Upaya Meningkatkan Perekonomian Rumah Tangga Ditinjau dari Ekonomi Syariah (Studi pada Pedagang di Pasar Tradisional Kabupaten Lebak).” UNIVERSITAS ISLAM NEGERI SERANG BANTEN, 2019.

[2] S. Ruswinarsih, "Aktivitas domestik dan publik perempuan kerja (studi terhadap perempuan pedagang kelontong di Pekapuran Raya Banjarmasin)," Kafaah $J$ Gend. Stud., vol. 3, no. 1, pp. 89-106, 2013.

[3] M. S. Simanjuntak, "Peran Perempuan dalam Meningkatkan Kesejahteraan Keluarga (Studi Kasus pada Perempuan Pedagang Sayuran di Pasar Induk Sidikalang)," 2018.

[4] D. Fujiati, "Perempuan Pedagang dan Pasar Tradisional," IAIN Pekalongan, vol. 9, no. 2, pp. 106124,2017

[5] S. Widodo, "Peran perempuan dalam sistem nafkah rumah tangga nelayan," in Seminar Nasional: Kedaulatan Pangan dan Energi. Fakultas Pertanian Universitas Trunojoyo, 2012.

[6] M. Bahzar, "Membangun Nasionalisme di Wilayah Perbatasan melalui Penguatan Modal Sosial," 2014.

[7] E. Sungkawati and R. Ratnawati, "Sistem Manajemen Kinerjaguna Meningkatkan Partisipasi Anggota Koperasi Wanita," Pros. Semnas Has. Penelit., 2016.

[8] E. Handoyo, "Modal Sosial dan Kontribusi Ekonomi Pedagang Sayur Keliling di Semarang," in Forum Ilmu Sosial, 2012, vol. 39, no. 2.

[9] P. Purnama, "Strategi Dagang Yang Diterapkan Pedagang Sayur Keliling Dalam Perspektif Ekonomi Islam Di Kecamatan Mapilli Kabupaten Polewali Mandar Sulawesi Barat." UIN Alauddin Makassar, 2017.

[10] Y. Kusumawati, "Peran Ganda Perempuan Pemetik Teh,” Komunitas Int. J. Indones. Soc. Cult., vol. 4, no. 2, 2012.

[11] D. E. Wibowo, "Peran ganda perempuan dan kesetaraan gender," J. Muwazah, vol. 3, no. 1, pp. 356364,2011

[12] N. Hidayati, "Beban ganda perempuan bekerja (antara domestik dan publik)," J. Muwazah, vol. 7, no. 2, pp. 108-119, 2015.

[13] N. Ramadhani, "Implikasi peran ganda perempuan dalam kehidupan keluarga dan lingkungan masyarakat," Sosietas, vol. 6, no. 2, 2016.

[14] A. I. Masitha, "Dampak sosial ekonomi revitalisasi pasar tradisional terhadap pedagang," J. Sos. Ekon.
Pekerj. Umum, vol. 2, no. 2, 2010.

[15] N. A. Hasbuan, "Analisis dampak relokasi pasar tradisional terhadap pendapatan pedagang sebelum dan sesudah relokasi ke pasar induk di kota Medan (studi kasus pasar Sutomo Medan)." Universitas Islam Negeri Sumatera Utara, 2017.

[16] Y. Wardhani, S. G. Prasetya, and D. A. Dharmantyo, "Faktor-Faktor Yang Mempengaruhi Pendapatan Pedagang Sayur Keliling Di Kota Bogor," Ekono Insentif, vol. 14, no. 1, pp. 39-53, 2020. 